\title{
$\mathrm{ECF}$ 漂白パルプの褪色防止について*
}

王子製紙株式会社 研究開発本部 製紙技術研究所 河江 綾乃，○内田 洋介

\section{Inhibition of Yellowing of ECF Bleached Hardwood Kraft Pulp}

\author{
Ayano Kawae and $\bigcirc$ Yosuke Uchida
}

Research Development Div. Pulp \& Paper Research Laboratory, Oji Paper Co., Ltd.

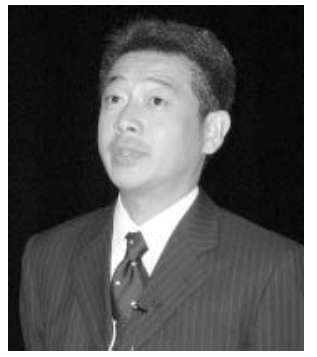

内田洋介

The aim of this work was to inhibit the heat-and moisture-induced yellowing of ECF bleached hard wood kraft pulp (LBKP) in acidic paper. We have already reported that one of the derivatives of hexenuronic acid (HexA) in LBKP, 5-formyl-2-furancarboxylic acid (FFA), causes yellowing, and that FFA might polymerize or react with pulp components to form new chromophoric groups 1 ).

In this study, it was shown that the carboxylic base of FFA interacts with that of glucuronic acid or galacturonic acid, resulting in strong yellowing. Therefore, it seems that preventing the reaction of carboxylic bases could be effective in suppressing this yellowing. We have discovered that polycarboxylic acids (for example, citric acid, tartaric acid, etc.) are useful as a yellowing inhibitor.

分類： $\mathrm{K}_{12}$ 無塩素漂白, $\mathrm{R}_{4}$ クラフトパルプ

1.はじめに

世界的な流れとして，環境負荷低減を目的としたパルプの ECF (Elementary Chlorine Free) 漂白法への転換が進んで いる。北欧，北米に追随する形で，日本でも ECF 漂白への 転換が進められており，王子製紙(株)においては，2006 年 6 月をもって全 BKP 製造工場の ECF 漂白への転換が終了し ている。

ECF 漂白転換後, 酸性紙の熱湿裉色という，今までに経 験しなかった新たな裉色問題が起きている。本裉色の特徵と しては，(1)広葉樹晒パルプを使用した酸性紙に特有，(2)二酸 化塩素を主体とした ECF 漂白パルプに特有，等が挙げられ， 機械パルプで頻繁に見られる光裉色とは全く異なった裉色で あり，原因究明とその対策が急務とされている。

筆者らは，この褪色原因について調查しており，ECF 漂 白パルプ中に残留したへキセンウロン酸が原因物質であり, 酸性下（酸性紙）の熱湿条件下でこのへキセンウロン酸が酸 加水分解されて 2 種のフランカルボン酸を生成して着色する と共に, さらにフランカルボン酸同士が反応, あるいは他の パルプ成分と反応し強く着色し, 褪色することを報告してい

*平成 18 年度年次大会講演（講演 No. A 15）
る ${ }^{1)}$ 。本報告では，褪色機構についてさらに詳細に調査する と共に，その抑制方法についても検討したので報告する。

\section{2. 実験}

\section{1 モデル化合物を使用した褪色実験}

まず，市販のろ紙（アドバンテック社製，No.2）を 0.1 $\mathrm{mol} / \mathrm{L}$ 硫酸溶液に浸せきし, 酸性ろ紙を調製した。次に $2-$ フランカルボン酸 (FA), 5-ホルミル-2-フランカルボン (FFA), 酸性糖としてグルクロン酸 (GlucA), ガラクッロ ン酸（GalacA），中性糖としてグルコース，キシロース，マ ンノースをそれぞれ $20 \mathrm{mmol} / \mathrm{L}$ に調整し, 各 $0.5 \mathrm{~mL}$ を任 意の組合せで混合し, 蒸留水で $3.5 \mathrm{~mL}$ に薄めた後, 酸性ろ 紙を浸せきさせた。前記ろ紙を風乾した後, 熱湿処理 $\left(80^{\circ} \mathrm{C}, 65 \% \mathrm{RH}, 24 \mathrm{~h}\right)$ した。処理前後のろ紙のb*を測定 し， $\Delta \mathrm{b} *$ を求め, 褪色の指標とした。また, 針葉樹晒クラ フトパルプ（NBKP）から酸性紙を調製し, 同様に前記モデ ル化合物を添加して，褪色の度合いを評価した。

\section{2 着色物質生成に関与する官能基の調査}

FFA と GlucAをそれぞれ $2 \mathrm{mmol}$ ずつ重水 $2 \mathrm{~mL}$ に溶か し， ${ }^{1} \mathrm{H},{ }^{13} \mathrm{C}, \mathrm{C}-\mathrm{H}$ NMR を測定した。また， $20 \mathrm{mmol} / \mathrm{L} の$

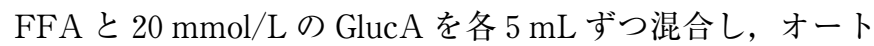
クレーブで加熱処理し $\left(121^{\circ} \mathrm{C}, 1 \mathrm{~h}\right)$, 反応液をエバポレー 
表 1 クエン酸ナトリウムを含むサイズプレス液の調製と その塗布

\begin{tabular}{c|c|c|c}
\hline \multirow{2}{*}{} & \multicolumn{3}{|c}{ 塗布量 $\left(\mathrm{g} / \mathrm{m}^{2}\right)$} \\
\cline { 2 - 4 } & 酸化澱粉 & 外添サイズ剤 & クエン酸ナトリウム \\
\hline ブランク & 1.50 & 0.20 & 0.00 \\
\hline テスト(1) & 1.50 & 0.20 & 0.25 \\
\hline テスト(2) & 1.50 & 0.20 & 0.50 \\
\hline テスト(3) & 1.50 & 0.35 & 0.50 \\
\hline
\end{tabular}

夕で蒸発乾固した後，重水置換し，同様にNMR を測定した。 反応前後の NMR 測定データを比較し, 着色物質生成に関与 する官能基を推定した。

\section{3 褪色抑制剂の探索}

ラボで調製した高へキセンウロン酸（HexA）含有広葉樹 晒クラフトパルプ (LBKP) (HexA 含有量 ; $19.8 \mu \mathrm{mol} / \mathrm{g}$, 白色度 ; $85.3 \%$ ）絶乾 $2 \mathrm{~g}$ をイオン交換水 $2 \mathrm{~L}$ に分散し, 硫 酸バンド $1.2 \%$ を添加し，酸性紙を調製した。前記酸性紙に， 褪色抑制剂として，対パルプ $5 \%$ の各種化合物（クエン酸， 酒石酸, リンゴ酸, 琥珀酸, マロン酸, イタコン酸, グリコ ール酸，乳酸）を含浸させ，熱湿処理し， $\Delta \mathrm{b} *$ を算出して， 褪色抑制効果を評価した。

2.4 クエン酸ナトリウム塗布量と褪色抑制効果

前記高 HexA 含有 LBKP をビーターで吒解し（Frs. 506 $\mathrm{m} l$ ), ロジンサイズ剤, カチオン化澱粉, 硫酸バンド, 歩留 向上剤をそれぞれ対パルプ $0.5 \%, 0.55 \%, 0.8 \%, 0.01 \%$ 添加し, 米坪 $60 \mathrm{~g} / \mathrm{m}^{2}$ の手抄き紙を調製した。この手抄紙に 対し, 酸化澱粉, 外添サイズ剤 (オレフィン系), クエン酸 ナトリウムの塗布量がそれぞれ $1.5 \mathrm{~g} / \mathrm{m}^{2}$, が $0.2 \mathrm{~g} / \mathrm{m}^{2}, 0$ 〜 $0.6 \mathrm{~g} / \mathrm{m}^{2}$ となるようにエッチングプロセッサでサイズプ レスした。シリンダードライヤで乾燥後, 熱湿処理し, 熱湿 処理前後の $\Delta \mathrm{b} *$ を求め, 褪色抑制に必要なクエン酸ナトリ ウムの塗工量を調査した。

\section{5 クエン酸ナトリウム外添による紙質への影響調査}

酸化澱粉, 外添サイズ剂 (オレフィン系), およびクエン 酸ナトリウムを所望の割合で混合して外添サイズ液を調製し, 工場製酸性紙（米坪； $59.1 \mathrm{~g} / \mathrm{m}^{2}$ ，外添なし）に対し，表 1 の塗布量となるようエッチングプロセッサでサイズプレスし た。シリンダードライヤで乾燥後, 強度, サイズ性および裉 色性を評価し，クエン酸ナトリウムの紙質への影響を調べた。

\section{3. 結果および考察}

\section{$3.1 \mathrm{ECF}$ 漂白パルプの裉色機構}

広葉樹材中のキシラン側鎖として存在する 4-O-メチルグ ルクロン酸の一部は, 蒸解工程でヘキセンウロン酸 (HexA) に変換すると言われている2 では, 塩素段でほぼ完全に分解, 除去され, 晒クラフトパル プ中に残留することはなかったが, ECF 漂白転換後, しば しばLBKP 中に残留し, 特に酸性紙に使用された場合に褪 色性を悪化させることからその存在が知られるようになった。

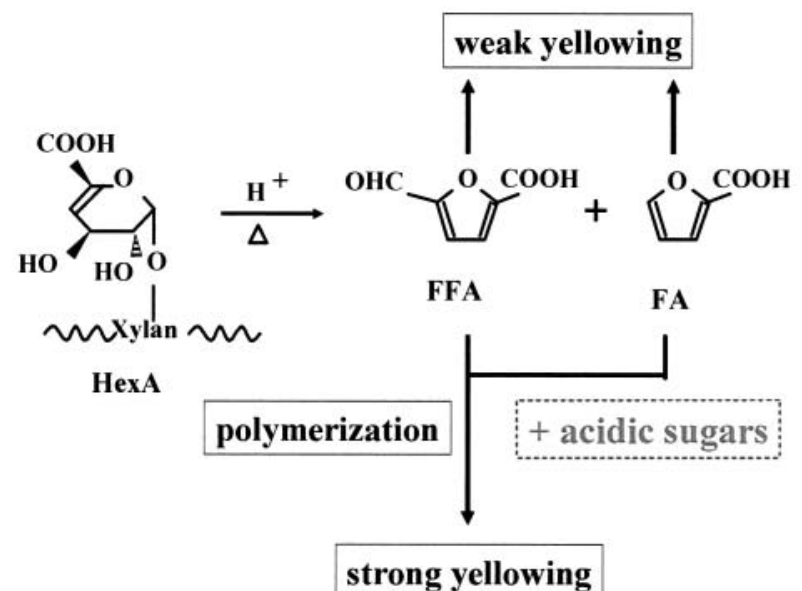

図 $1 \mathrm{ECF}$ 漂白パルプの螁色機構 $(\text { 推定 })^{1)}$

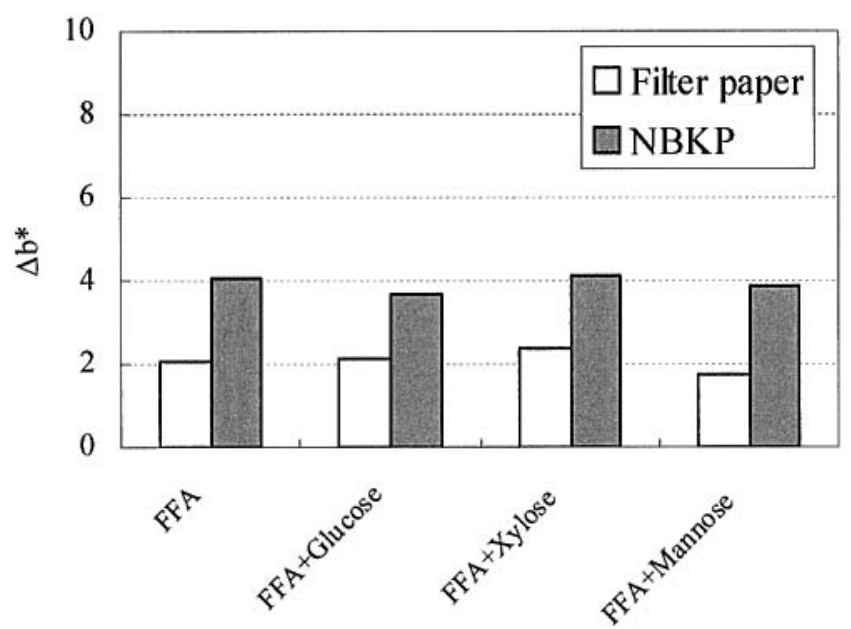

図 2 FFA と中性糖の熱湿褪色への相互作用

$\mathrm{ECF}$ 漂白で頻繁に使用される二酸化塩素ではHexA を完 全に分解，除去することは難しく，また，アルカリ性過酸化 水素では全く分解できない( ${ }^{3,4}$ ことから, 二酸化塩素段とアル カリ性過酸化水素段を組み合わせて漂白した ECF 漂白 LBKP ではこの問題が起こり易い。演者らは, HexA に起因 するこの褪色機構について調査しており, 酸性紙として熱湿 条件下におかれると, HexA が酸加水分解され, 2 種のフラ ンカルボン酸を生成して着色すると共に, さらにフランカル ボン酸同士が反応，あるいは他のパルプ成分と反応し強く着 色し，褪色することを報告している1（図 1）。

今回は, 褪色過程でフランカルボン酸と反応する, “他の パルプ成分”について調査した。まず，フランカルボン酸の 反応相手として, 広葉樹晒クラフトパルプ中に最も多く存在 する中性糖（グルコース, キシロース, マンノース）の可能 性について調査したが, ろ紙上に中性糖とフランカルボン酸 を共存させても，熱湿褪色の度合いが変わらないことから， 中性糖は裉色時のフランカルボン酸の反応相手ではないと判 断された（図 2）。

一方，基紙をろ紙から NBKP（HexA 含量は痕跡程度）に 変えると, FFA を添加した時の熱湿褪色が大きくなったこ とから, フランカルボン酸の褪色時の反応相手が中性糖以外 
のパルプ成分であることが再確認された。

次に, BKP 中のパルプ成分として中性糖の次に多いと考 えられる酸性糖（グルクロン酸：GlucA，ガラクツロン酸： GalacA）の可能性について調查した（図 3)。中性糖の場合 と同じ実験をした結果，熱湿条件下で酸性糖は自身でも着色 するが，フランカルボン酸と共存すると強く着色し, 裉色す ることがわかった。つまり, 酸性糖は螁色時のフランカルボ ン酸の反応相手となりえることが判明した。このことから， HexA 含有 LBKPを原料とした酸性紙の熱湿裉色は, (1) HexA の酸加水分解によるフランカルボン酸の生成, (2)フラ ンカルボン酸同士，あるいはパルプ中の酸性糖との反応の 2 段階で起こると推測された（図 4)。

\section{2 阻害剂添加による褪色抑制}

1）褪色反応に関与する官能基について

上述のように, HexA 含有 LBKP を原料とした酸性紙の 熱湿褪色反応は 2 段階で起こると推測される。特に 2 段目の 反応では強く着色するため， 2 段目の反応を抑制できれば螁 色を大幅に軽減することができる。2 段目の反応抑制を検討 するにあたり，まず 2 段目の反応に関与する官能基について 調べた。フランカルボン酸として FFA, 酸性糖として GlucA

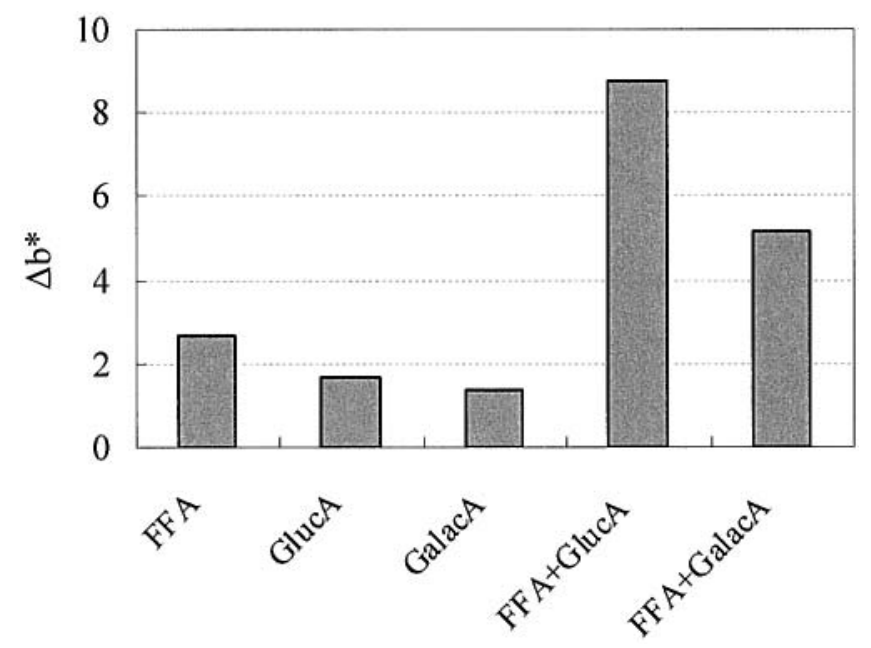

図 3 FFA と酸性糖の熱湿裉色への相互作用

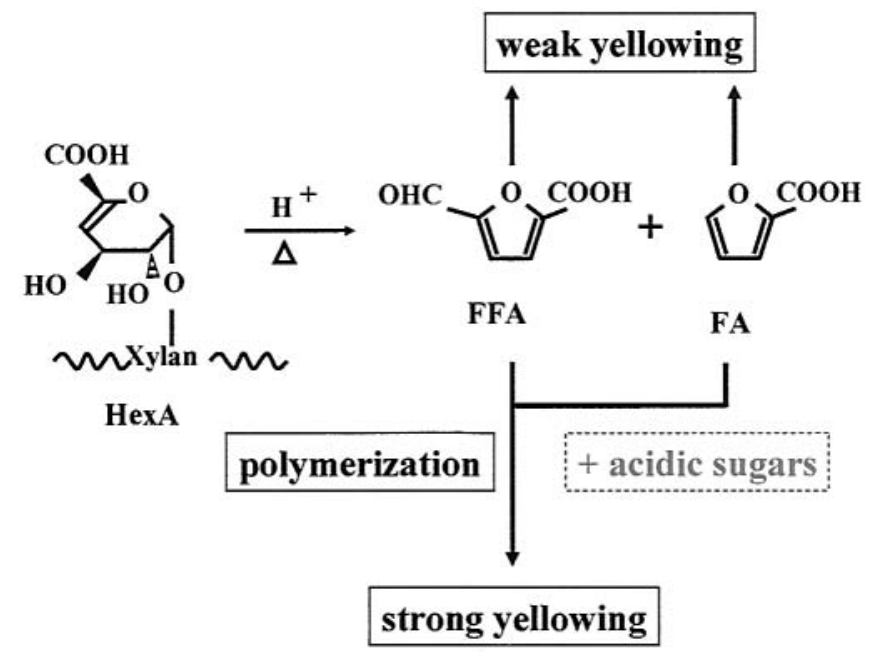

図 4 ECF 漂白パルプの褪色機構（推定）
を用い，両者を熱湿条件下で反応させ，反応前後の NMR ス ペクトルデータから反応に関与する官能基を推定した（図 5）。 その結果, FFA,GlucAのいずれもカルボキシル基が反応に 関与していることが示唆された。

2）阻害剂添加による褪色抑制

上記結果から，カルボキシル基を有する化合物を添加すれ ば，フランカルボン酸同士，あるいはフランカルボン酸と酸 性糖の反応を阻害し, 裉色を抑制できると考え, その探索を 行った。カルボキシル基を有する比較的単純な化合物として, クエン酸, 酒石酸, リンゴ酸, 琥珀酸, マロン酸, イタコン 酸，グリコール酸，乳酸を選択し，高 HexA 含有 LBKP を 原料とした酸性紙に添加して, その熱湿裉色抑制効果を調べ た。その結果, クエン酸, 酒石酸, リンゴ酸, 琥珀酸, マロ ン酸, イタコン酸に効果が見られ, 1 分子内に複数のカルボ キシル基を有する化合物に抑制効果があることがわかった (図 6,7)。なお，ポリアクリル酸のような高分子化合物であ っても複数のカルボキシル基を有する化合物であれば裉色抑 制効果があることを確認している

3）クエン酸ナトリウム添加による褪色抑制効果と紙質へ の影響調查

1 分子内に複数のカルボキシル基を有する化合物として, 比較的入手容易なクエン酸ナトリウムを用いて, その外添量

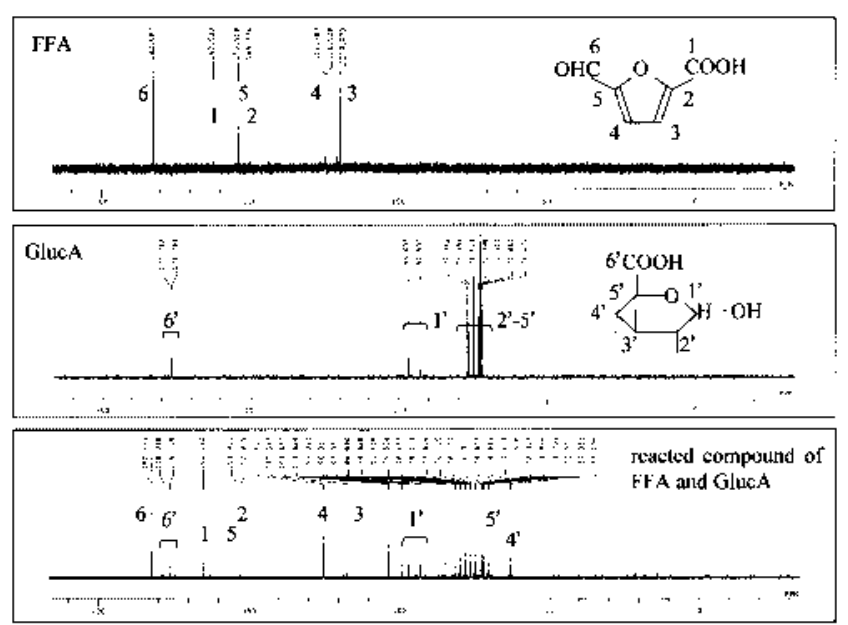

図 5 FFA，GlucA，および反応物の NMR スペクトル
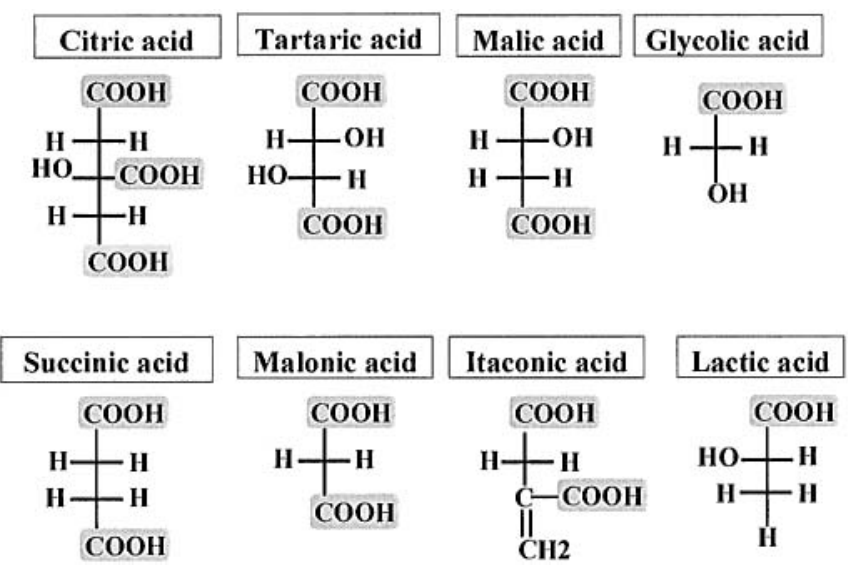

図 6 試験に使用した化合物 


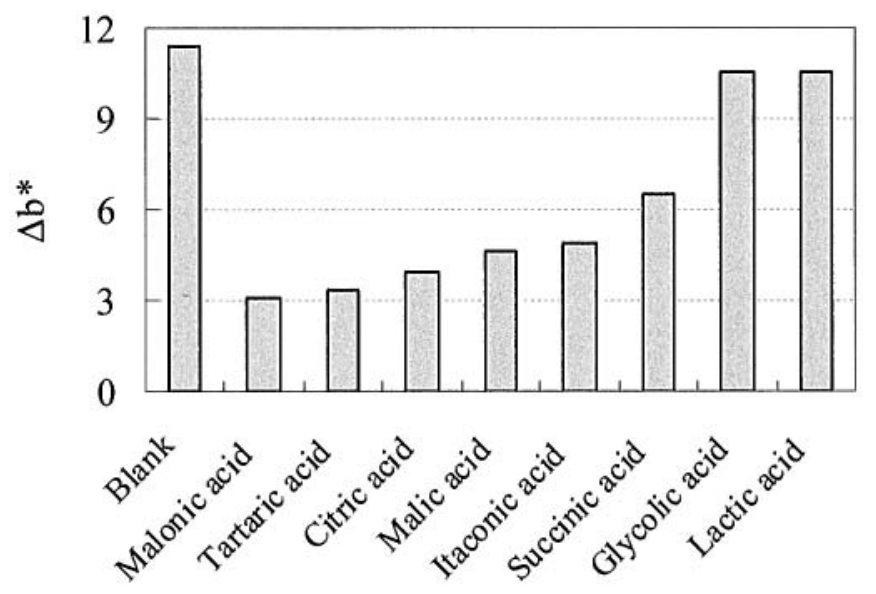

図 7 各化合物の褪色抑制効果

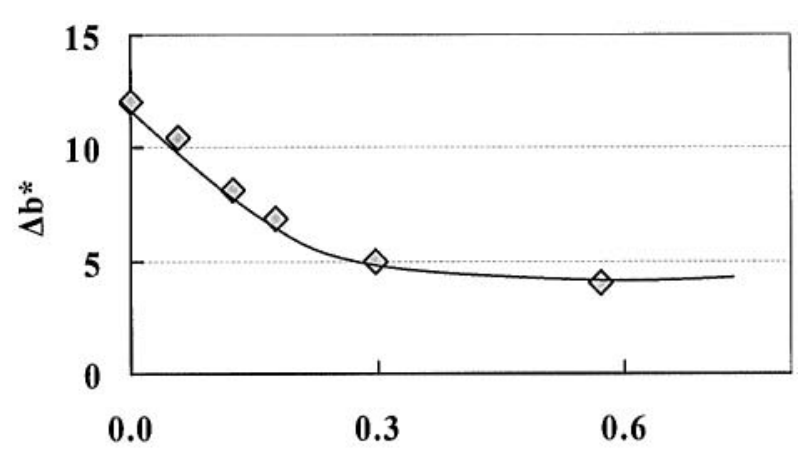

クェン酸ナトリウムの塗布量 $\left(\mathrm{g} / \mathrm{m}^{2}\right)$

図 8 クエン酸ナトリウムの塗布量と褪色抑制効果

表 2 クエン酸ナトリウム塗布による紙質への影響

\begin{tabular}{c|c|c|c|c|c|c}
\hline & $\begin{array}{c}\text { Tear index } \\
(\mathrm{MD}) \\
\left(\mathrm{mN} \cdot \mathrm{m}^{2} / \mathrm{g}\right)\end{array}$ & $\begin{array}{c}\text { Tear index } \\
(\mathrm{CD}) \\
\left(\mathrm{mN} \cdot \mathrm{m}^{2} / \mathrm{g}\right)\end{array}$ & $\begin{array}{c}\text { Bleaking length } \\
(\mathrm{MD}) \\
(\mathrm{km})\end{array}$ & $\begin{array}{c}\text { Bleaking length } \\
(\mathrm{CD}) \\
(\mathrm{km})\end{array}$ & $\begin{array}{c}\text { Internal bond } \\
\text { strength } \\
\left(\mathrm{J} / \mathrm{m}^{2}\right)\end{array}$ & $\begin{array}{c}\text { Stöckigt sizing } \\
\text { degree } \\
(\mathrm{s})\end{array}$ \\
\hline Blank & 7.9 & 8.8 & 8.5 & 3.5 & 535 & 28 \\
\hline Test 1 & 8.8 & 8.8 & 8.1 & 3.6 & 541 & 29 \\
\hline Test 2 & 8.5 & 9.5 & 8.2 & 3.5 & 529 & 27 \\
\hline Test 3 & 8.3 & 9.2 & 8.4 & 3.5 & 511 & 26 \\
\hline
\end{tabular}

と褪色抑制効果の関係について調查した（図 8)。クエン酸 ナトリウムの場合, 塗布量は $0.3 \mathrm{~g} / \mathrm{m}^{2}$ 程度で十分褪色抑制 効果があり，過剩な塗布量を要しないことがわかった。

次に，クエン酸ナトリウムを塗布量した場合の紙質への影 響を調査した（表 2)。なお, クエン酸ナトリウムの塗布量 は表 1 の通りである。

表 2 に示すように, クエン酸ナトリウムを $0.25 \sim 0.5 \mathrm{~g} / \mathrm{m}^{2}$ 塗布してもシート強度, サイズ度, 等に影響は与えない。こ のことから, クエン酸ナトリウム叙布による ECF 漂白パル プの褪色抑制方法は有効であると結論付けることができる。

\section{4. ま め}

ECF 漂白 LBKP をベースとした酸性紙の熱湿螁色機構に ついて調査すると共に, その機構を利用した褪色抑制方法に ついて検討した。調査の結果, ECF 漂白 LBKP をベースと した酸性紙の熱湿褪色は, LBKP 中に含まれるへキセンウロ ン酸が原因物質であり, 熱湿条件下で酸加水分解により $2-$ フランカルボン酸あるいは 5 -ホルミル-2-フランカルボン酸 に転換し, 重合あるいはパルプ中の酸性糖と反応して着色物 質を生成し, 褪色することがわかった。前記 2 種のフラン化 合物の反応阻害による裉色抑制方法について検討した結果, クエン酸, リンゴ酸, 等のカルボキシル基を複数持つ化合物 の添加が有効であることがわかった。
また, 別の褪色抑制方法としては, 酸性紙にアルカリ薬品 を外添し紙面 $\mathrm{pH}$ を中和して, HexA の酸加水分解を抑制す る方法 ${ }^{5,6)}$, 酸処理 ${ }^{7)}$, 高温二酸化塩素処理 ${ }^{8}$ 等を導入し, HexA を除去する方法を挙げることができる。

\section{References}

1) A. Kawae and Y. Uchida : Appita Journal 58 (5) 378 (2005)

2) A. Teleman, V. Harjunpaa, M. Tenkanen, J. Buchert, T. Hausalo, T. Drakenberg and T. Vuorinen : Carbohydrate Research (272) 55 (1995)

3) J. Buchert, A. Teleman, V. Harjunpaa, M. Tenkanen, L. Viikari, and T. Vuorinen: Tappi Journal 78 (1) 125 (1995)

4) Y. Kawamura, A. Kakehi and Y. Uchida : Japan Patent 2006-37327

5) K. Kisara, H. Watanabe, H. Wakasa and Y. Uchida : Japan Patent 2005-82893

6) K. Kisara, A. Kawamura and Y. Uchida : Japan Patent 2005-350781

7) T. Vuorinen, J. Buchert, A. Teleman, M. Tenkanen and P. Fagerstrom : Int. Pulp Bleach. Conf. 43 (1996)

8) D. Lachenal and C. Chirat: IPBC proceedings 95 (1998) 